\title{
The Impact Of Partnership Program To The Marketing Capabilities On Fostered SMEs
}

\author{
Novi Nur Hayatti \\ Department of Management, \\ University of Trunojoyo Madura \\ Mohammad Arief \\ Department of Management, \\ University of Trunojoyo Madura \\ M. Alkirom Wildan \\ Department of Management, \\ University of Trunojoyo Madura
}

\begin{abstract}
The aim of the paper is to exploring the impact of Partnership Program to the Marketing Capabilities On Fostered SMEs. Specifically, this paper focuses to investigate and understand an event or problem that has occurred by collecting various information which is then processed to obtain a solution to the problems uncovered can be resolved. The method of this study used a descriptive qualitative. Our analysis are based on data from 4 Fostered SMEs owners and 1 informant. The result suggest that the Partnership has not been effective against marketing capabilities. Our finding indicated that there's no training to the fostered SMEs from SOEs to increasing their marketing capability, specially in monitoring and training activity. We argue that its contrary to the regulation concerning the partnership program from government. Therefore, we recommendation for a SOEs to develop and supervise the business activities of Fostered SMEs and training on marketing by focusing on Digital Marketing and Branding. Finaly, this paper also reported for the future research.
\end{abstract}

Keywords: Partnership Program, SMEs, SOEs, Marketing Capabilities

\section{INTRODUCTION}

Many empirical studies has shown that SMEs are believed to spur economic growth, a source of innovation, and can contribute to the country and to create new jobs (Aziz \& Rusland, 2009). But, another empirical research has shown that it's not easy to developed of SMEs. There's many reasoning why it happened, such difficulty for SMEs to obtaining a capital, a low quality of human resources, high preasure for competitiveness and low marketing access (Indonesian Banking Development Institute, 2015). Similarly, Aziz \& Rusland, 2009) show that there's two main problem for SMEs. First, they has a low quality of human resources. Second, the limitation on productive resources, specially on marketing, capital, and technology.

Based on Article 66 of Law No. 19 of 2003 states that a government can provide special assignment to SOEs to perform the functions of public benefit with regard to the purpose and objective of SOEs. Furthermore, an Article 88 confirms that SOEs should allocate the net income for purposes of developed small business and community. One of the recommendation to solve the problems of the community economy and to increasing the role of SOEs is the implementation of partnership program. That program noted on ministerial regulation of SOEs No. PER-05/MBU/2007. The point of that regulation highlight about the intent and purpose of SOEs to the establishment, whereby they not only the pursuit of profit, but fell 
actively provide guidance and assistance to economically weak groups, co-operatives and Community Sector (SOEs, 2016).

The Government regulation explains that the SOEs must be constantly to monitoring the implementation of the Partnership program to ensure achievement of the implementation. To implement it, SOEs must be create a guidance for a partner to acquired a loan or production tools whereby it can be use to increase production and sales. Includes of that guidance is the facilitation for SMEs to get a special loan fund grants. To knowing that mechanism running well, it's important for SOEs to evaluation. The evaluation measurement can be seen from the relatedness between fund disbursement and the partnership program that was run. When it found the gaps, then it can be concluded that the program has a problems.

"In this partnership program, distribution has been done well. However, assistance in undergoing training for SMEs as well as an understanding of the business / marketing have not done the maximum" (Informant)"

An addition, we has an information that there's one SMEs which have attempted to handle in the field of marketing. But the application used didn't match with expected, so they must be looking for ways to deal with problems in the marketing field. When it continues, there's possibility for SMEs to fail in business practice. In line, Scheers (2011) argue that the SMEs failure because they not pay attention to the marketing aspect for the business. Furthermore, marketing capabilities is a requirement for excavation opportunities, product creation, creation of added value and communication to customers (Wahyudi, 2012). It can help develop a business, specially for SMEs.

Every business, including SMEs, must be has a good marketing capabilities. With that capabilities, they can be creating a new customers. In addition, it will be impact to the establishment of a loyal customers (Inan \& Kop, 2018; Banterle, et al, 2008). From literature perspective, several authors define marketing capabilities as the integrative processes designed to apply collective knowledge, skills and resources of the firm to market-related needs of the business, enabling the business to add value to its goods and services and meet competitive demands (Vorhies, 1998). Similarly, Wu (2013); Morgan, Katsikeas \& Vorhies, 2012) explained that marketing capabilities in terms of a firm's ability to use available resources to perform marketing tasks by gathering effective information and responding it through marketing planning. Based on previous argument, we're interest to exploring marketing capabilities implementation more deeply.

To measuring a firms marketing capabilities, we used a several perspectives from authors. Delivering a great marketing capabilities for a firm can be conducted through promotions activity (Slotegraaf \& Pauwels, 2008; Day, 2011). They argue that promotions has a great influence on long-term sales for high-equity brands. Brand equity is a sources of competitive advantage and superior performance (Day, 1994). Marketing literature shown that brand equity become a measurement for a firm's marketing activity. Weerawardena (2003) highlights that strong brand can be charge premium prices in foreign markets to enhance their profitability. In other word, brand equity will be a great determinant to measure an marketig activity.

Meanwhile, preliminary study also found that SMEs have a several limitation. One of them is they have a low innovation (Supriyadi \& Ekawati, 2014). The other side, previous study explain that innovation become a one of main subject to measure a firm capability (Day, 1994). An innovative firm tended to will make a product and service recognition. To reach that phase, 
they must have a market sensing capability whereby it can be used to identifying customers need and response. Hence, we argue that SMEs must have a strengthen market analysis, so that it's showing their capabilities. In line with Guenzi \& Troilo (2006), the ability to solve customer problems can be allowed while there is a innovation.

Marketing capabilities also related with a firm ability to show a difference from competitor. The difference content can be focuses on products and services (Weerawardena, 2003; Morgan, et al., 2009; Potočan, 2013). There's several ways for a firm to differentiate it, one of them with decrease the the customers search cost and perceived risk (Morgan, et al., 2009). When a firm can be differentiate it, then they will tend to received a higher revenue through a potential customers which interest with product and services offered.

In this paper, we exploring the impact of partnership program to the marketing capabilities on fostered SMEs. Spesifically, there's two contributions for the knowledge development from this domain. First, this paper focuses to investigate and understanding a problem that occurred by collecting various information. Second, we will procesess it to obtaining a solution to the problems uncovered can be resolved.

\section{Partnership program}

\section{LITERATURE REVIEW}

Hasfah (2000: 43) points out the partnership is a business strategy that is done by two or more parties in a period of time to achieve the principle of mutual benefit with the raising and needy. According Wibisono (2007: 89) the partnership program is a program improving the capabilities of small businesses in the form of a loan and the purchase of production so that small business into a formidable independent.

In line with Government Regulation No. 44 of 1997 partnership program is a cooperative effort between small businesses with a medium or large businesses with coaching and development with due regard to the principle of mutual need, are mutually reinforcing and mutually organized through patterns that correspond to the nature and purpose of business partnership.

Discussion this study analyzes the partnership program because this program is ongoing and relate directly to SMEs. The success of this program will promote economic progress of society at large. The Partnership Program is a program that helps SMEs in the form of loans and development in the environment around SOEs operate

\section{Marketing Capabilities}

A large body of literature, capabilities are viewed as the processes and routines which a firm will transforms all of the resources into valuable outputs (Reed and DeFillippi 1990; Teece et al., 1997). Many authors also describe that capability involve a complex activity which combine between pattern of skills and knowledge. A firm capability will be more valuable if it's a sources of advantage, particularly when a rivals difficulty to compete away. It can be happen if the competitors difficult to observe a firm (Day, 1994).

In 2004, the American Marketing Association (AMA) define marketing is an organizational function and a set of processes for creating, communicating and delivering value to customers and for managing customer relationships in ways that benefit the organization and its stakeholders. Over the years, the AMA has revising the definition of marketing, specially related constructs such as marketing strategy. It's imply that marketing science not just standing to the one construct, but it will combined with another sciences field. The 
consequence, marketing science will be more complex. The strategic management literature suggests that a firm must be has a basic competencies, and it will be develop with considering an environment factors (Christmann, 2000; Hart, 1995). A requirements that must be fulfilled by firm which will be develop a competencies. They need requiring higher-order learning proficiencies. Yet, some authors state that competencies is insufficient. It means that a firms must has another factor. According to the resource-based view, competitive strategies depends on a firm capabilities (Barney \& Zajac, 1994).

From marketing literature, there's a difference terms in marketing capabilities. A marketing capabilities framework can be identified based on linked market-based assets with cash-flow growth (Srivastava et al.'s, 1998), market sensing and the firm's ability to link with end-user and channel customers (Day, 1994), superior product market (Dutta, Narasimhan and Rajiv 1999; Morgan et al., 2003) and financial performance outcomes (Krasnikov and Jayachandran 2008; Morgan et al., 2009b).Hence, marketing scholars view theory and operationalization of marketing capabilities as a different competencies (Song, Nason, Benedetto, \& Anthony, 2008).

In this study, we focus on the specific marketing capabilities, and use them through combination with the findings. Finally, our finding will be lead to the some recomendation.

FRAMEWORK

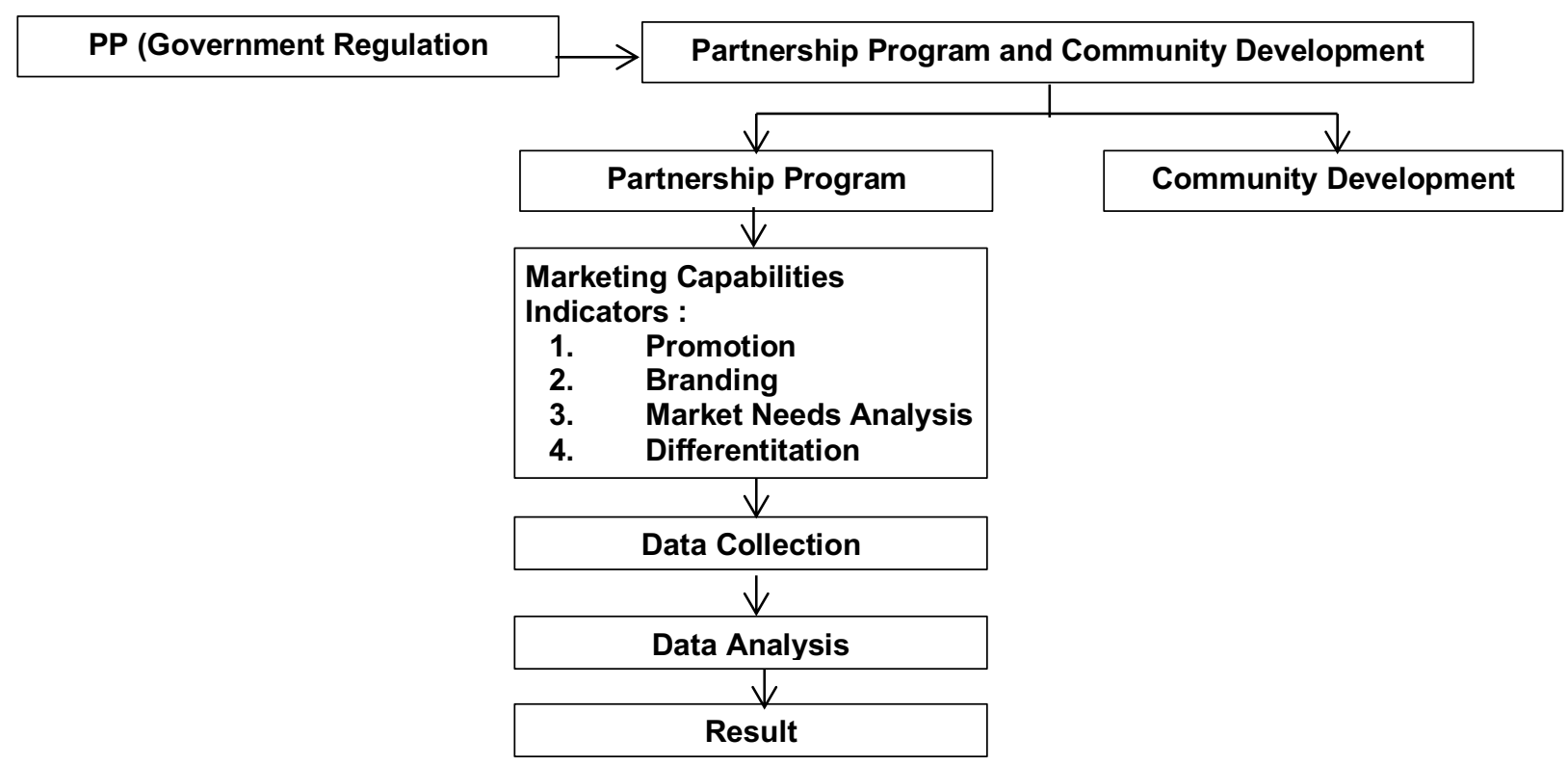

\section{RESEARCH METHODS}

The subject of this paper focused to the 4 Fostered SMEs with incorporated or recorded in the criteria established partners as well as the products sold are included in a superior product. There is one informant as the validator. The approach in this study using case studies. This type of approach is used to investigate and understand an event or problem that has occurred by collecting various information which is then processed to obtain a solution to the problems uncovered can be resolved. The technique of collecting data using in-depth interviews, observation and documentation. All interviews has recorded on audio and transcribed for each word. The amount of interviews is consistent for each respondent and used the same technique. Data analysis techniques consists on data reduction, data presentation and conclusion (Sugiono, 2014). 
Descriptive information on respondents interviewed in the first step of the research process exhibited in Table 1.

Table 1. Respondent

\begin{tabular}{|c|c|c|c|}
\hline Respondent & Gender & Product & Position \\
\hline 1 & Female & Jam and fruit syrup & Owner \\
\hline 2 & Female & Snack & Owner \\
\hline 3 & Female & Snack and drink & Owner \\
\hline 4 & Female & Drink & Owner \\
\hline
\end{tabular}

The questionare is organised in the 4 categories, which reflected the main dimensions of the marketing capability. The total amount of questionare is 12 questions, and each has a sub categories. Each of the variable instrument exhibited in Table 2.

Table 2. Variable Instrument

\begin{tabular}{|c|c|c|}
\hline Variable & Measurement & Instrument \\
\hline \multirow{4}{*}{$\begin{array}{l}\text { Marketing } \\
\text { capability }\end{array}$} & Promotion & $\begin{array}{l}\text { 1. Promotion activity } \\
\text { 2. Introduce product } \\
\text { 3. The amount of consumers } \\
\text { 4. The role of SOEs to develop a promotion }\end{array}$ \\
\hline & Brand & $\begin{array}{l}\text { 1. Product brand } \\
\text { 2. Introduce a brand } \\
\text { 3. The role of SOEs to develop a brand }\end{array}$ \\
\hline & Market analysis & $\begin{array}{l}\text { 1. Market analysis from fostered SMEs } \\
\text { 2. Consumers planned } \\
\text { 3. The role of SOEs to develop a market analysis }\end{array}$ \\
\hline & Differentiation & $\begin{array}{l}\text { 1. Product differentiation } \\
\text { 2. The role of SOEs to develop a product differentiation }\end{array}$ \\
\hline
\end{tabular}

\section{RESULTS AND DISCUSSION}

\section{The Impact of Partnership Program To The Promotion Activity}

Based on data analysis, we found that most Fostered SMEs using a promotion activity with word of mouth (WOM) approach. This is done by promoting the first in the neighborhood of SMEs live and also through family or relatives. Promotion of mouth to mouth is a marketing strategy that takes customers to talk (do the talking), promoting (do the promotion) and sell (do the selling) for free and full power. Promotions by this method can increase the confidence of society with regard to the level of satisfaction and quality assuredness given. It's recorded from respondent statement as follow:

"To promotion activity, we use an information from another people, also through an event in the market. When any activities which push a tourist to come, we opened a stands and demonstred our product". (S1)

"When there are fairs or if the a tourist arrives, we promote our product to the stands. We also promote our product through a people with exploite a social media." (S4)

Similarly, another respondent also explain that promotion practice has been done with provide a souvenir to the tourist. In addition, promotion also conducted with distribute a brochures. That statement has been recorded as follow.

"Yes, when our guest had arrives (tourist), we're opening a stands. Its not just give us an income, but also we get a lessons. Moreover, we has been done a promotion as a word of mouth, also distribute brochures which written a product list". (S2) 
In addition to the introduction of the SMEs use tester manner in which this matter accentuate the flavor of the product. The taste of the product is believed the key to the consumer will be back again to buy the product and also on the promotion of social and market mediated plice just some of the research subjects who already use it due to the lack of human resources or their knowledge in terms of promoting in the media. Of ways that done by the SMEs they feel that it is effective to introduce a subscription products.

The research subjects also explore that the promotion is always an increase in terms of customers and products sold. However, it has become a challenge for the SMEs how they always keep consumers do not abandon their product will quiet even enthusiasts. The SMEs mentioned that their efforts in order to increase consumers or not missing them always puts the taste, always pay attention to product quality and innovation. In addition, for products increasingly known to many people they want more extensive marketing outreach.

Furthermore, from the results of research related to how the manager of partnerships in helping SMEs with regard to the promotion of SME business, the subject of the study revealed that the manager of the partnership was to help but it is not sustainable. The SMEs want any training or guidance on the promotion of business because it is so needed by the business it is caused by the limitations of qualified human resources and limited knowledge of SMEs about it. The SMEs want more extensive marketing efforts this case would require the intervention of the manager of the partnership to address the problems faced by SMEs. Without guidance or coaching on an ongoing basis can result in the SMEs can not flourish.

Indeed promotion is one important factor, where it can have an impact on consumer decisions to buy products of SMEs. This method is done by communicating SME products to be offered to consumers so that consumers can identify products sold SMEs and consumers interested in making a purchase.

\section{The Impact of Partnership Program To The Branding}

Consumers view a brand as an important part of the product, and product purchases can add value to a product (Kotler and Armstrong, 2012). This shows that the brand is something that could help consumers to make purchases and to define products that benefit them. To optimize a brand name, several respondent confirmed that they make a logos and stickers for product that offered. One of the respondent states as follow:

"Yes, we make a logos or stickers for our products". (S4)

Based on the data and the results of research that has been described above it can be seen that the selection of brand name still use their own thoughts or suggestions from others, no careful consideration to the selection of brand name each product SMEs. Supposedly the SMEs actually choose a brand name to sell the value of the product or the name easily recognized by the public or consumers or unacceptable to consumers.

Besides three SMEs in mind that they use the logo, business card on its product packaging that are considered by SMEs means that they can do to introduce their products and easier for consumers to find more products. But not all SMEs know how to introduce the brand, no one SMEs reveals that there is no rationale for introducing its brand. This is unfortunate because the views of the proceeds of this SMEs should be more visible to a wider customer visits also in terms of the length of the product and demand hold too much. Again, this is due to lack of qualified human resources and knowledge businesses are still minimal in marketing their products. In introducing the brand, the fostered SMEs revealed that they focus on product 
quality and taste of the product. He revealed that the quality and taste of the product can trigger the consumer repeat purchases of the product it sells.

Furthermore, from the results of research related to how the manager of partnerships in helping SMEs related to SME business branding, all SMEs confirm the same thing that none of the manager of partnerships in helping Fostered SMEs. It is unfortunate though it is highly desirable by SMEs, where the research subjects expressed a desire held some sort of training, workshops that support the sustain capabilities of their businesses, because the SMEs believe the presence of it can promote the progress of business, and hopes they can find out how their products are known widely. The problems found in the field experienced by most SMEs that lack of Human Resources (HR) of SMEs. They confirms that there's no training and coaching from SOEs relate with how to create a brand name. Even, they feels that it important for them. The need for training and coaching with the effort to improve the quality of human resources in running a business. That statements recorded as follow.

"There's no training or something like that which conducted from SOEs about how to develop a brand name". (S2)

"From SOEs, we're never invited to follow a training about that. Actually, we want to following a training. So, to introduce a brand is yet". (S4)

\section{The Impact of Partnership Program To The Market Needs}

Analyzing the needs of the market is one important activity for economic practitioners, businesses and companies primarily in the marketing department. The information coming from the market provide a basis for the production, how the product should be provided to the market. It can be also estimated the level of sales in the future, so that businesses be able to prepare for the predicted sales.

Market needs do not always constant and is influenced by many factors. Without proper production planning, it is not impossible these SMEs will suffer a loss because if a much larger production volume exceeded the demand for it will pile up in the warehouse. In actual conditions, several respondent confirms that they has done a productions planning. To do the activity, they considering a weather factor. The respondent confirms as follow.

"We also consider a weather to produced a product. When a summer, we usually producing more product. It caused many people needed a product. Just it”. (S1)

Another confirmation has mentioned from respondent, as follow:

"I not just consider a weather to producing a product, but also a guest. When a guest arrives, they has an agendas, and it knows from a village officials. That information show the guest residence, etc. For foreign guest, I produce not too much product, and vice versa. Related with a weather, I customize it. If rainy season, I made a warm drink". (S4)

SMEs or businesses must be able to take advantage of market information to determine consumer response to the product, so it can be taken into consideration in determining the amount of the amount of product to be produced. By calculation then all the components involved in the production process can be controlled, such as the number of goods to be manufactured, materials and equipment needed in the production process to be executed, the amount of funds or capital, and supply products that are needed. It is the same as that expressed by the SMEs that analyzes the needs of the market is very important for them to do, because of the analysis they can produce exact. 
From interviews conducted tehadap the subject of research on the analysis of market requirements in mind that not all SMEs know the right way to do that, because the lack of human resources and the knowledge of it. However, some SMEs are known in analyzing their market needs to see the season or the weather, for example, when the summer they will be much produce because that is where the demand for its products more and more. Furthermore, when the rainy season, there is one of the SMEs that produce much more there is also a little because of the rising market demand and also down.

In addition, the SMEs will promote innovation products where they see what else are sought after in the market, such as the taste of the product innovation. And equally important in terms of packaging, the SMEs realize that in terms of consumer packaging often interested in buying their products so that SMEs continue to innovate regarding packaging.

Based on the results of interviews conducted there were significant obstacles in analyzing market needs namely the problem of capital or funds expended to increase production, and product innovation in terms of packaging. SMEs will complain of inadequate funding because it takes a lot of money for it.

Furthermore, from the results of research related to how the manager of partnerships in helping SMEs related to the analysis of market needs of SMEs, it is known that the manager of the partnership has not been helpful to the problem. No training or coaching associated Candy SOEs should be done by companies belonging to the SOEs. Here the SMEs expressed a desire to be held the training that encourages the advancement of SMEs due to limited human resources known to the SMEs so that these activities is the development of SMEs in the future. With their guidance can also control or be able to evaluate the business operation of SMEs. That explanation has been confirm from respondent as follow:

"There's no some training from SOEs related with market analysis". (S1)

\section{The Impact of Partnership Program To The Differentiation Capabilities}

Product differentiation effect on consumer purchasing decisions. It aims to increase competition among companies. Product differentiation is the difference in a product with these differences, the consumer will have the consideration in the purchase of certain products (Simamora \& Situmeang, 2018). In operationalization, several Fostered SMEs have been showing a difference for the product. Expressly, it come from the respondent confirmation as follow:

"We make a product which not produce in the market, so it different with the others. There's many beverage products in the market, but we have a different taste and crispness. From the uniqueness, our product more crunchy and it gives a good taste. Sometimes, we have a same recipes with the others, but the taste a difference. Because our product not much in the market, so there's many consumers which search it.To compete, we maintain the taste, quality, also our product didn't use preservative". (S2)

"...that is make an innovation because there's a same product that produce by a competitors. Therefore, to difference with the other, we use an innovation focuses to the taste and packaging, also maintain a quality". (S4)

From interviews with study subjects above can be seen that the taste of a product is a very important. In reaching the level of customer satisfaction by Drummond and Brefere (2010:13) taste is a way of selecting foods that should be distinguished from the taste of the food. In using 
a good taste of all SMEs using groceries still fresh, clean and suitable standards of health from the health department. Next, is innovation here the SMEs products using such variation is / volume of product for every taste variations. This is expected to give customer satisfaction, which in turn will increase the purchasing decision.

In addition, the SMEs mentioned in terms of packaging (packaging), according Nuryanti and Rahman (2008) revealed the packaging may affect consumer decisions to purchase. This is consistent with the statement expressed by Buchari Alma (2005: 160) that the consumer always has a certain consideration in the purchase of goods and first appeal is focused on the form, beauty or performance of wrapping or packaging. At the first appearance of the product or at the time of the introduction of the role of packaging is very important because this is the first introduction for consumers. The quality of products is also mentioned here that the SMEs believe that product quality is very important. With the good quality and reliable, the products will always be embedded in the minds of consumers because consumers are willing to pay some money to buy a quality product.

Furthermore, from the results of research related to how the manager of partnerships in helping SMEs with regard to the products of SMEs, it is known that the manager of the partnership has helped in that respect but do not run sustainable means there is not always similar activities. Though it is highly desirable or needed by SMEs. And note also SMEs feel there has never once received guidance. This is most likely due to less inequality in information resulting in ignorance of the existence of the event was held. Linked with a discussion regarding the above products help or guidance from the manager of the partnership The management can encourage creativity partnership expected growing SMEs. Judging also from the SME in this case is good enough, but still need the support of the manager of the partnership because it requires skilled people due to lack of qualified knowledge of the SMEs. It thus needs to be done as a strategy of how the product can be different and can compete in the market is not easy to do.

\section{The Impact of Partnership Program To The Marketing capabilities of Fostered SMEs}

From the discussion on the promotion, branding, market needs analysis and differentiation can be concluded there was no significant impact on the development of marketing capabilities of SMEs, it is because the whole of SMEs claim to do marketing in accordance with their respective capabilities. The problems experienced by SMEs is the lack of Human Resources (HR). This is in line with Situmorang (2008) SMEs have not been too has the aspect of a good education or knowledge regarding the development in business management. So it takes the intervention of the manager of the partnership to the benefit of SMEs which will also have an impact on the manager of a partnership when the SME successfully. SMEs want the periodic monitoring or training of SMEs in an effort to improve the quality of human resources in the marketing aspect as the base to run a business, here is clear that in the absence of training or monitoring of the partners had violated the Regulation of the Minister of the article governing the Partnership Program, Article 8 paragraph 3 and article 9, paragraph 1 in article 8, paragraph 3 clearly reveals the SOEs coach must still monitor the implementation of the partnership to ensure achievement of the program implementation, and article 9, paragraph 1 reveals the presence of the burden of marketing guidance to its established partners.

\section{MANAGERIAL IMPLICATIONS}

From the research finding, there's not enough information for Fostered SMEs related with training and coaching from SOEs. Even if any information, they think it not effective. In line with that finding, several information has been highlight from an informant. They confirm that training and coaching for SOEs has performed. Yet, they difficulty to determine the training 
scheme. That is because not all of the Fostered SMEs uses a technology as a promotion tools. Based on this fact, there's a recommendation from an informant that its usefull for Fostered SMEs to follow a training, spesifically in the E-Commerce scheme. It is expected that ecommerce can make alternative for SMEs for the promotion. This is supported by Maryama (2013) which revealed the benefits perceived by businesses when implementing e-commerse is to increase sales turnover, increasing the number of customers, as a means of promotion and to expand the business.

Based on that recommendation, we have a several suggestion for Fostered SMEs as exibit in Table 3.

Table 3. Managerial Implications

\begin{tabular}{l|l|l}
\hline \multicolumn{1}{c|}{ Training Scheme } & \multicolumn{1}{c}{ Objectives } & \multicolumn{1}{c}{ Activity } \\
\hline $\begin{array}{l}\text { Technology as the } \\
\text { development of } \\
\begin{array}{l}\text { Fostered SMEs as a part } \\
\text { of promotions activity }\end{array}\end{array}$ & $\begin{array}{l}\text { Fostered SMEs can be optimize } \\
\text { promotional activities for a business, thus } \\
\text { it can inform the existence of the product } \\
\text { clearly. A clearly product not just changed } \\
\text { the customers perception, it also } \\
\text { encourage customers to purchase }\end{array}$ & $\begin{array}{l}\text { Training scheme on promotion } \\
\text { media which used a technology, } \\
\text { Training scheme focuses on E- } \\
\text { commerce }\end{array}$ \\
\hline $\begin{array}{l}\text { Managing brand } \\
\text { strategy }\end{array}$ & $\begin{array}{l}\text { Fostered SMEs can be optimize product } \\
\text { brand for a business activities, to more } \\
\text { competitive. Strong brands will be impact } \\
\text { to the develop a network, then it causes } \\
\text { creating a customers trust. }\end{array}$ & $\begin{array}{l}\text { Training scheme on brand } \\
\text { name, symbols and tagline, } \\
\text { Training scheme focuses on } \\
\text { build the brand equity }\end{array}$ \\
\hline
\end{tabular}

\section{CONCLUSIONS AND RECOMMENDATIONS}

Their coaching and training for the partners had set in Candy SOEs, so that the target SMEs gain knowledge in order to develop and prosper the efforts being run. From the information obtained, almost all SMEs built yet additionally received coaching and training. Only a few SMEs are expressing is helped by the manager of the partnership is long and even then no way sustainable. That is, the manager of the partnership have not done coaching and training to the maximum, especially in the marketing of SME products. In SOEs candy, there are chapters that explain that the burden of development earmarked for training and marketing by $20 \%$ of the typical walking. But the manager of the new partnership to realize funds in the form of coaching load bazaar activity only. Of hope and suggestions put forward by Fostered SMEs, the manager of the partnership is expected to provide training and coaching according to the needs and wishes of Fostered SMEs so as to realize the chapter governing the funding and development burden with good partnership program.

In addition to coaching and training, SMEs admitted lack of supervision or monitoring efforts. Whereas monitoring and supervision needs to be done regularly and periodically in order to know the business development of partners and be the evaluation of the existing shortcomings and problems. Therefore it takes a team to supervise or monitor the business activities of the partners. So we can conclude that the Partnership has not been effective in the marketing of SMEs products Fostered thus less a significant impact on the effectiveness of Fostered SMEs indicated by the absence of coaching as well as training in marketing given by the person in charge of monitoring and training where it is contrary to the regulation concerning the partnership program No. Per-03/MBU/12/2016.

From the analysis, there's a same suggestions for the manager of the partnership to maximize the partnership program, especially regarding the development and training in the marketing 
of SME products. Formed a dedicated team oversees the development and activities of Fostered SMEs and handle service the partners in resolving a problem or discussion in the development effort. This suggestion aims to be the manager of business development and partnerships to know what is happening in the field. So it becomes an evaluation to correct deficiencies and resolve existing problems in the field, especially the business activities of Fostered SMEs. The next suggestion is holding a training where the main focus on marketing. The training is divided into two aspects, namely promotion and branding where the training discusses promotions that are suitable for SMEs and ways of branding for business products that are run.

Furthermore its important for the fostered SMEs to following training and coaching. While it done, they can developing a bisnis for the future. If happen training and coaching program will be make the fostered SMEs to aware of the knowledge.

\section{Reference}

Aziz A, A Herani Rusland. 2009. The role of Bank Indonesia to Support Development of Micro, Small, and Medium. Jakarta: Center for Education and Studies Kebanksentralan

Banterle, A, Carraresi L., and Stranieri S. 2008, Marketing Management Capabilities os SMEs; an empirical analysis in the EU, 12th Congress of The European Association of Agricultural Economist - EAAE.

Barney, J.B., and Zajac, E.J. 1994. Competitive organizational behavior Toward an organizationally based theory of competitive advantage. Strategic Management Journal, 15,5

Christmann, P. 2000. Effects of "best practices" of environmental management on cost advantage: The role of complementary assets. Academy of Management Journal, 43(4), 663.

Day, George S. 2011. Closing the Marketing Capabilities Gap, Journal of Marketing Vol. 75, 183-195.

Drummond KE \& Brefere LM. 2010. Nutrition for Foodservise and Culunary Professional 's. Seventh Edition. New Jersey. John Wiley \& Sons. Page 3-4

Dutta, shantanu, Om Narasimhan and Surendra Rajiv. 1999. Success in high-technology markets: Is marketing capability critical?', Marketing Science, 18 (4), 547-68.

Guenzi, Paolo and Gabriele Troilo. 2006. Developing marketing capabilities for customer value creation through Marketing-Sales integration, Industrial Marketing Management 35. 974-988, doi:

10.1016/j.indmarman.2006.06.006

Hart, 0. 1995. Corporate governance: Some theory and implications. The Economic Journal, 105 (430), 678-689.

Hasfah, Mohammad Jafar. 2000. Kemitraan Usaha Konsepsi dan Strategi. Jakarta: Pustaka Sinar Harapan

Inan, Guven Gurkan and Aysegul Eda Kop. 2018. Marketing Capability Development in Micro Manufacturing Enterprises, American Journal of Industrial and Business Management, 8, DOI: 10.4236/ajibm.2018.81001.

Kotler, P. and Armstrong, G. 2012. Principles of Marketing. 14th Edition, Pearson Education Limited, Essex, England.

Krasnikov, Alexander and Satish Jayachandran. 2008. The relative impact of marketing, research and development, and operations capabilities on firm performance. Journal of Marketing, 72 (4), 1-11.

Maryama. 2013. Penerapan E-Commerce Dalam Meningkatkan Daya Saing Usaha. Jurnal Liquidity STIE Ahmad Dahlan Jakarta Vol. 2 No.1 Hal. 74-79

Morgan, Neil A., Shaoming Zou, Douglas W. Vorhies and Constantine S. Katsikeas. 2003. Experiential and informational knowledge, architectural marketing capabilities, and the adaptive performance of export ventures. Decision Sciences, 34 (2), 287-321.

Morgan, Neil A., Rebecca J. Slotegraaf and Douglas W. Vorhies, 2009, Linking marketing capabilities with profit growth, Intern. J. of Research in Marketing, 26, 284-293, doi:10.1016/j.ijresmar.2009.06.005

Morgan, Neil A., Douglas W. Vorhies and Charlotte H. Mason. 2009b. Market orientation, marketing capabilities, and firm performance. Strategic Management Journal, 30 (8), 909-20. 
Morgan,Neil A., Constantine S. Katsikeas, and DouglasW. Vorhies. 2012. Export Marketing Strategy Implementation, Export Marketing Capabilities, and Export Venture Performance. Journal of the Academy of Marketing Science, 40(2), 271-89

Potočan, Vojko. 2013. Marketing Capabilities For Innovation Based Competitive Advantage In The Slovenian Market, Innovative Issues and Approaches in Social Sciences, Vol. 6, No. 1.

Reed, richard and robert J. deFillippi. 1990. Causal ambiguity, barriers to imitation, and sustainable competitive advantage. Academy of Management Review, 15(1), 88-102.

Scheers, LV. 2011. SMEs' marketing skills in South Africa challenges. African Journal of Business Management. Vol. 5, p. 7.

Simamora and Situmeang. 2018. Analisa Pengaruh Diferensiasi Produk Terhadap Keputusan Pembelian Konsumen Pada Showroom Garuda Sibolga. Jurnal Insitusi Politeknik Ganesha Medan Juripol Vol.1 No.1.

Situmorang, J., 2008. Strategi UMKM Menghadapi Ilkim Usaha Yang Tidak Kondusif. Infokop, Volume XVI, p. 92.

Slotegraaf, R. J., \& Pauwels, K. 2008. The impact of brand equity and innovation on the long-term effectiveness of promotions. Journal of Marketing Research, 45(3), 293-306.

SOEs, K., 2016. The Partnership Program and Community Development SOES. [Online] Available at: http://infopkbl.bumn.go.id/index.php/home/index/50 [Accessed 2018]

SOEs, the SOEs Minister Regulation K. 2107. Per-03/MBU/12/2016 dated December 16, 2016. [Online] Available at: http://idih.bumn.go.id/lihat/PER-03/MBU/12/2016 [Accessed 2018]

Song, M., Nason, R. W., Benedetto, D. and Anthony, C. 2008. Distinctive marketing and information technology capabilities and strategic types: A cross-national investigation. Journal of International Marketing, 16(1), 4-38.

Sugiyono, 2012. Metode Penelitian Kuntitatif, Kualitatif dan R\&D. Bandung: Alfabeta

Supriyadi and Ratna Ekawati. 2014, The Effect of Strategic Partnership On Innovation Capability and Business Performance Of Garment Industry In West Java - Indonesia, International Journal Of Scientific \& Technology Research, Volume 3, ISSUE 12.

Teece, d.J., g. Pisano and A. Shuen. 1997. Dynamic capabilities and strategic management. Strategic Management Journal, 18(7), 509-35.

Vorhies, D. W. 1998. An investigation of the factors leading to the development of marketing capabilities and organizational effectiveness. Journal of Strategic Marketing, 6(1), 3-23.

Wahyudi, S. 2012. Entrepreneurial Branding and Selling.Yogyakarta: Graha Ilmu.

Weerawardena, J. 2003. The role of marketing capabilities in innovation-based competitive advantage. Journal of Strategic Marketing. Vol.: 11, pp.: 15-35.

Wibisono, Joseph. 2007. Dissecting Concepts \& Applications CSR (Corporate Social Responsibility. Gresik: Fascho Publishing.

Wu, J. 2013. Marketing capabilities, institutional development, and the performance of emerging market firms: a multinational study. International Journal of Research in Marketing, Vol. 30 No. 1, pp. 1-15. 